\title{
A novel genetically-obese rat model with elevated 11 beta-hydroxysteroid dehydrogenase type 1 activity in subcutaneous adipose tissue
}

\author{
Sakamuri SS Vara Prasad', Anamthathmakula Prashanth', Chodavarapu Pavan Kumar', Sirisha J Reddy', \\ Nappan V Giridharan², Ayyalasomayajula Vajreswari ${ }^{*}$
}

\begin{abstract}
$11 \beta$-hydroxysteroid dehydrogenase type $1(11 \beta$-HSD1) catalyzes the conversion of inactive glucocorticoids to active glucocorticoids and plays an important role in the development of obesity and metabolic syndrome. 11 $\beta$-HSD1 activity is lower in liver and higher in omental adipose tissue of obese rodent models like obese zucker rats, Ob/Ob and $d b / d b$ mice. Here, we report the 11ß-HSD1 activity in liver and adipose tissue of lean and obese rats of WNIN/Ob strain, a new genetic rat model of obesity. 11ß-HSD1 activity in liver, omental and subcutaneous adipose tissues of 3 month-old male WNIN/Ob lean and obese rats was assayed. As observed in other rodent models, 11ß-HSD1 activity was lower in liver and higher in omental adipose tissue. In contrast to other rodent obese models, WNIN/Ob obese rats had elevated $11 \beta-H S D 1$ activity in subcutaneous adipose tissue, which is in line with the observation in human obesity. Here, we conclude that dysregulation of $11 \beta$-HSD1 in WNIN/Ob obese rat model is identical to human obesity, which makes it an excellent model for studying the effect of $11 \beta$-HSD1 inhibitors in ameliorating obesity and metabolic syndrome.
\end{abstract}

\section{Introduction}

Glucocorticoids are essential for the regulation of metabolism, normal functioning of nervous, cardiovascular, skeletal and immune systems. They are also implicated in the pathogenesis of obesity and metabolic syndrome as evidenced by the fact that, elevated systemic glucocorticoid concentration in Cushing's syndrome results in the development of metabolic syndrome including visceral obesity. The role of plasma glucocorticoids in the development of idiopathic obesity is not clear, as their levels are not altered or sometimes even low in obese patients [1].

Tissue sensitivity to glucocorticoids depends on plasma hormone levels, density of glucocorticoid receptors and local metabolism of glucocorticoids by $11 \beta$ hydroxysteroid dehydrogenases. $11 \beta$-hydroxysteroid dehydrogenase type 1 (11 $\beta$-HSD1) catalyzes the conversion of inactive glucocorticoids (cortisone in humans and 11-dehydrocorticosterone in rodents) to active

\footnotetext{
* Correspondence: vaj_lipidresearch@yahoo.com

'Department of Biochemistry, National Institute of Nutrition, Jamai Osmania

PO, Hyderabad-500 604, Andhra Pradesh, India

Full list of author information is available at the end of the article
}

glucocorticoids (cortisol in humans and corticosterone in rodents) [2]. It is highly expressed in liver, adipose tissue and brain [2]. Another enzyme, 11 $\beta$-HSD2 catalyses the reverse reaction and expressed in distal nephron, sweat and salivary glands [3].

Recently, it has been reported that $11 \beta-H S D 1$ plays an important role in the development of obesity and insulin resistance. In obese zuckar rats and in obese human subjects, $11 \beta$-HSD1 activity is higher in adipose tissue, where as in liver it is low [4-6]. The role of 11 $\beta$-HSD1 in obesity and metabolic syndrome is further supported by the transgenic animal model studies. Adipose-specific overexpression of $11 \beta$-HSD1 in mice resulted in the development of majority of metabolic syndrome features including visceral obesity and insulin resistance [7], where as $11 \beta$-HSD1 knock-out in mice resulted in the development of resistance to diet-induced obesity [8]. Recently, selective inhibitors of $11 \beta-H S D 1$ are developed to treat obesity and metabolic syndrome.

Rodent models of obesity provide valuable information on the molecular mechanisms underlying the development of obesity and its associated complications. WNIN/Ob rat 
obese strain is developed from 80-year-old inbred wistar rat colony at National centre for Laboratory Animal Sciences (Hyderabad, India) [9]. They exhibited all biochemical characteristics of leptin-resistant obese zuckar rats. These rats are hyperphagic, hyperinsulinemic, hyperleptinemic and have dyslipidemia [9]. Preliminary studies on WNIN/Ob obese rats show no molecular defects in leptin and leptin receptor [unpublished data]. Further, molecular mutation leading to the development of obesity in these obese rats is under investigation.

Here, we hypothesize that WNIN/Ob obese rats have altered 11 $\beta$-HSD1 enzyme activity in liver and adipose tissue as observed in other obese rodent models. To test our hypothesis, we studied the $11 \beta-H S D 1$ enzyme activity in liver, adipose tissue and skeletal muscle of 3 month-old WNIN/Ob lean and obese rats.

\section{Materials and methods Animals}

3 month-old WNIN/Ob male lean and obese rats $(n=6)$ were obtained from National Centre for Laboratory Animal Sciences (NCLAS, India) and study was approved by Institutional Animal Ethical Committee. Animals were acclimatized in individual cages under controlled conditions of temperature $\left(22 \pm 1^{\circ} \mathrm{C}\right)$, humidity $(50-60 \%)$ and light (12:12 h light-dark cycle). Stock diet and water were provided ad libitum. After overnight fasting, blood was collected and the animals were sacrificed by decapitation. Tissues were dissected out, weighed and stored at $-80^{\circ} \mathrm{C}$ until the analysis.

\section{Adiposity Index (\%)}

Adiposity index was calculated by dividing total weight of omental, retroperitoneal and epididymal adipose tissue with the total bodyweight and multiplied by 100 .

\section{Plasma parameters}

Plasma corticosterone (Siemens, Los Angeles, USA), insulin (BARC, India) and leptin (Linco Research, USA) levels were measured by radioimmunoassay (RIA). Plasma glucose and triglyceride levels were measured by Commercial Kits (Biosystems, Spain). Tumor necrosis factor- $\alpha$ (TNF- $\alpha$ ), Interleukin-6 (IL-6) and Macrophage chemoattractant protein-1 (MCP-1) were estimated by Milliplex Rat cytokine immunoassay kit (Millipore, USA).

\section{Insulin resistance and glucose tolerance}

Insulin resistance was assessed from homeostasis model assessment of insulin resistance (HOMA-IR). HOMA-IR was calculated from fasting glucose and insulin values using the following formula.

HOMA $-I R=($ fasting insulin $[\mu U / \mathrm{ml}] \times$ fasting glucose $[\mathrm{mmol} / \mathrm{l}]) / 22.5$
Oral glucose tolerance test was performed to measure the glucose tolerance. After an overnight fast, glucose $(200 \mathrm{~g} / \mathrm{l})$ was administered oro-gastrically at a dose of $2.0 \mathrm{~g} / \mathrm{kg}$ body weight and blood samples were collected from supraorbital at 0, 30, 60 and $120 \mathrm{~min}$. Glucose and insulin levels were measured at all time points.

Glucose tolerance was calculated during OGTT by calculating Area under curve (AUC) for insulin and glucose by the trapezoidal method [10].

\section{$11 \beta$-HSD1 activity}

$11 \beta$-HSD1 functions as a reductase in vivo, reactivating corticosterone from inactive 11-dehydrocorticosterone. However, in tissue homogenates, dehydrogenase activity predominates, hence $11 \beta$-HSD1 activity was measured by conversion of corticosterone to 11-dehydrocorticosterone [11]. Post nuclear fractions from liver and omental adipose tissue were prepared by centrifuging tissue homogenate at $1000 \mathrm{~g}$ for $20 \mathrm{~min}$. $11 \beta$-HSD1 activity was measured in post nuclear fractions of liver and omental adipose tissue by incubating in duplicates at $37^{\circ} \mathrm{C}$, in Krebs-Ringer buffer containing $0.2 \%$ glucose,

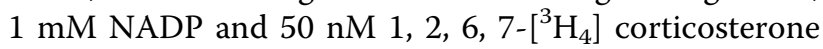
(Amersham, UK). Conditions were optimized to ensure first order kinetics, by adjusting protein concentrations for liver $(40 \mu \mathrm{g} / \mathrm{ml})$, adipose tissue $(1 \mathrm{mg} / \mathrm{ml})$ and skeletal muscle $(1 \mathrm{mg} / \mathrm{ml})$. After incubation (30 min for liver and $6 \mathrm{~h}$ for adipose tissue and skeletal muscle), steroids were extracted with ethyl acetate. Ethyl acetate was evaporated under dry nitrogen and steroids were resuspended in mobile phase (50\% water, $30 \%$ acetonitrile and $20 \%$ methanol). Steroids were separated by HPLC using reverse phase $\mathrm{C} 18$ column and radioactive counts from substrate and product peaks were calculated by online scintillation counter (IN/US systems, UK). Enzyme activity was expressed as percentage of substrate conversion.

\section{Statistical analysis}

Results were expressed as means \pm S.E of six animals from each phenotype. Statistical significance was determined by student's t-test and comparisons were made between lean and obese phenotype.

\section{Results}

Body weights, tissue weights and adiposity index

At 3-months of age, WNIN/Ob obese rats had significantly higher bodyweights (1.7 fold) as compared to their lean counter parts (Table 1). Adiposity index was significantly higher in obese rats (5.4 fold) as compared to their age and sex-matched lean rats (Table 1). Weights of liver, retroperitoneal, epididymal and omental fat depots were also significantly higher (1.7 fold, 5.4 
Table 1 Physical parameters in 3 month-old WNIN/Ob lean and obese rats

\begin{tabular}{lcc}
\hline & Lean $(\mathbf{n}=\mathbf{6})$ & Obese $(\mathbf{n}=\mathbf{6})$ \\
\hline Body wt (g) & $307 \pm 21$ & $543 \pm 13^{*}$ \\
Adrenal wt (mg) & $37.8 \pm 1.9$ & $48.0 \pm 1.5^{*}$ \\
Adrenal/body wt & $0.12 \pm 0.004$ & $0.09 \pm 0.004^{*}$ \\
Adiposity index (\%) & $1.0 \pm 0.03$ & $5.60 \pm 0.04^{*}$ \\
Liver (g) & $10.3 \pm 0.37$ & $17.6 \pm 0.04^{*}$ \\
Omental adipose tissue (g) & $0.36 \pm 0.04$ & $1.96 \pm 0.06^{*}$ \\
Epididymal adipose tissue (g) & $1.44 \pm 0.12$ & $10.5 \pm 0.08^{*}$ \\
Retroperitoneal adipose tissue (g) & $1.84 \pm 0.24$ & $15.8 \pm 0.04^{*}$ \\
\hline
\end{tabular}

Values are mean \pm S.E of 6 rats. Values with ${ }^{*}$ mark are significant at $P<0.05$ level (by student's $t$ test). Comparisons were made between lean and obese phenotypes.

fold, 7.3 fold and 8.6 fold respectively) in obese rats as compared to lean rats (Table 1). Adrenal weights were significantly higher ( 1.3 fold) in obese rats as compared to lean rats, where as adrenal to bodyweight ratio were significantly lower $(0.7$ fold $)$ in obese rats as compared to lean rats (Table 1).

\section{Plasma parameters}

Plasma corticosterone levels were significantly elevated (2 fold) in obese rats as compared to those of lean rats (Table 2). Fasting insulin and leptin levels were also significantly higher (29.4 and 14.2 fold respectively) in obese rats compared to lean rats (Table 2). Plasma triglyceride levels were significantly higher ( 4.5 fold) in obese rats as compared to lean rats (Table 2). There were no significant changes in the plasma levels of MCP- 1 and IL- 6 in obese rats as compared to their lean counter parts (Table 2). Although TNF- $\alpha$ level was detectable in lean rats, it was not in detectable range in obese rats (Table 2).

Table 2 Plasma parameters in 3 month-old WNIN/Ob lean and obese rats

\begin{tabular}{lcc}
\hline & Lean $(\mathbf{n}=\mathbf{6})$ & Obese $(\mathbf{n}=\mathbf{6})$ \\
\hline Corticosterone $(\mathrm{ng} / \mathrm{ml})$ & $213 \pm 34$ & $433 \pm 50^{*}$ \\
Insulin $(\mu \mathrm{U} / \mathrm{ml})$ & $7.0 \pm 3.6$ & $206 \pm 23^{*}$ \\
Triglycerides $(\mathrm{mg} / \mathrm{dl})$ & $46.5 \pm 3.0$ & $212 \pm 29^{*}$ \\
Glucose $(\mathrm{mg} / \mathrm{dl})$ & $80.0 \pm 2.0$ & $86.0 \pm 4.7$ \\
HOMA-IR & $1.4 \pm 0.8$ & $52.5 \pm 7.0^{*}$ \\
Glucose AUC $(\mathrm{mmol} / \mathrm{l})$ & $304 \pm 13$ & $472 \pm 31^{*}$ \\
Insulin AUC $(\mu \mathrm{U} / \mathrm{ml})$ & $5.1 \pm 1.2$ & $32 \pm 2.8^{*}$ \\
Glucose AUC/Insulin AUC $(\times 1000)$ & $74 \pm 14$ & $15 \pm 1.4^{*}$ \\
Leptin $(\mathrm{ng} / \mathrm{ml})$ & $1.0 \pm 0.1$ & $14.2 \pm 1.8^{*}$ \\
TNF- $\alpha(\mathrm{pg} / \mathrm{ml})$ & $3.0 \pm 1.6$ & $\mathrm{Nd}$ \\
IL-6 $(\mathrm{ng} / \mathrm{ml})$ & $191 \pm 62$ & $57.5 \pm 35$ \\
MCP-1 $(\mu \mathrm{g} / \mathrm{ml})$ & $0.3 \pm 0.1$ & $2.5 \pm 2.3$ \\
\hline
\end{tabular}

Values are mean \pm S.E of 6 rats. Values with ${ }^{*}$ mark are significant at $P<0.05$ level (by student's $t$ test). Comparisons were made between lean and obese phenotypes. $\mathrm{Nd}$, non-detectable.

\section{Insulin resistance and glucose tolerance}

Insulin resistance calculated by HOMA-IR is significantly higher (37 fold) in obese rats compared to age and sex-matched lean rats (Table 2). Glucose AUC and insulin AUC were significantly higher (1.5 fold and 6.2 fold respectively) in obese rats compared to lean rats (Table 2). Glucose to insulin AUC ratio was significantly lower (4.9 fold) in obese rats compared to lean rats (Table 2).

\section{$11 \beta$-HSD1 activity in omental and subcutaneous adipose tissue}

$11 \beta$-HSD1 activity was significantly higher (4.4 fold, 2.8 fold respectively) in omental and subcutaneous adipose tissues of 3-month old WNIN/Ob obese rats as compared to those of age and sex-matched lean rats (Figure 1A\&1B).

\section{$11 \beta$-HSD1 activity in liver and skeletal muscle}

$11 \beta$-HSD1 activity was significantly lower ( 0.6 fold) in liver of obese rats as compared to that of age and sexmatched lean rats (Figure 1C). Skeletal muscle (quadriceps) $11 \beta$-HSD1 activity was not different between 3 month old WNIN/Ob lean and obese rats (Figure 1D).

\section{Discussion}

In this study, we reported $11 \beta$-HSD1 enzyme activity in the peripheral tissues of novel genetically-obese rats of WNIN/Ob strain. WNIN/Ob obese rats had higher plasma corticosterone levels and heavier adrenal glands, indicating elevated hypothalamus-pituitary-adrenal (HPA) axis activity. They also have lower11 $\beta$-HSD1 activity in liver and higher activity in omental and subcutaneous adipose tissue. To our knowledge, this is the first genetic rodent model of obesity, exhibiting higher $11 \beta$-HSD1 activity in subcutaneous adipose tissue.

Glucocorticoids play an important role in adipocyte biology. Active glucocorticoids, cortisol (in humans) and corticosterone (in rodents) are essential for the differentiation of pre-adipocytes into mature adipocytes [12]. $11 \beta$-HSD 1 in adipose tissue is known to increase the local concentration of active glucocorticoids and thereby induce preadipocyte differentiation. This is further supported by cell culture studies, where $11 \beta-H S D 1$ inhibition has been shown to decrease cortisone-induced differentiation of pre-adipocytes [13]. Further, the role of $11 \beta-H S D 1$ in adipocyte differentiation and in obesity is confirmed by transgenic studies. Transgenic mice overexpressing 11 $\beta$-HSD1 in adipose tissue have developed visceral obesity with increased preadipocyte differentiation [7]. In leptin-resistant obese zucker rats, 11 $\beta$-HSD1 activity is elevated in omental adipose tissue and no change is observed in subcutaneous adipose tissue [4]. In leptin-deficient $o b / o b$ mice and in leptin-resistant $d b / d b$ mice, 11 $\beta$-HSD1 activity is higher in omental adipose 


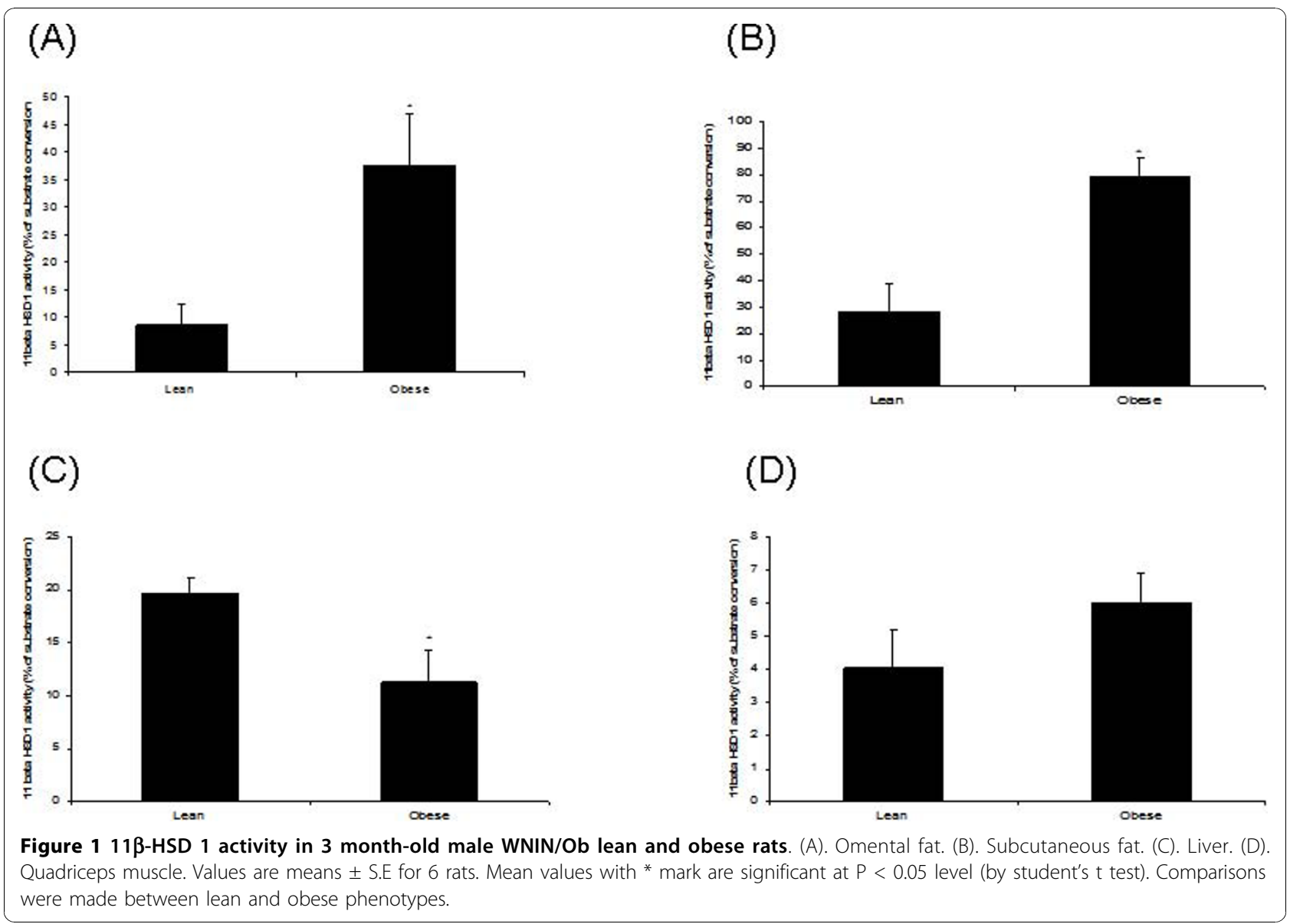

tissue and lower in subcutaneous adipose tissue [10]. In recently reported polygenic obese mice model and in diet-induced obese mice, 11 $\beta$-HSD1 activity is lower in omental and subcutaneous adipose tissue [14,15]. In human obesity, 11 $\beta$-HSD1 activity is higher in subcutaneous adipose tissue, however in omental adipose tissue the observations are inconsistent $[5,6]$. The newly studied WNIN/Ob obese rat had elevated $11 \beta$-HSD1 activity in omental adipose tissue. They also had higher enzyme activity in subcutaneous tissue, which is contrast to the observations made with other obese rodent models, and in agreement with the observations in human obesity. Although these obese rats had higher enzyme activity in omental and subcutaneous adipose tissue under fasting condition, interestingly, the enzyme activity is decreased significantly in fed-state as compared to lean rats (unpublished data).

In addition to the gene mutation that caused obesity, the observed higher $11 \beta$-HSD1 activity in omental and subcutaneous adipose tissue, might contribute to the development of obesity in this model. The exact mechanism responsible for the observed higher $11 \beta$ HSD1 activity in adipose tissue of WNIN/Ob obese rats can not be explained, unless the mutation is identified. However, the observed higher plasma corticosterone, insulin and leptin levels might be responsible for enhanced $11 \beta$-HSD1 activity, as these molecules upregulate $11 \beta$-HSD1 expression in adipocytes [16-18].

Glucocorticoids antagonize insulin signaling in various tissues and thus implicated in the development of insulin resistance [19]. 11 $\beta$-HSD1 negatively influences tissue insulin sensitivity by generating local active glucocorticoids. $11 \beta-H S D 1$ knockout mice have improved insulin sensitivity, on the contrary transgenic overexpression of $11 \beta$-HSD1 in adipose tissue of mice results in insulin resistance $[7,20]$. In obese zuckar rats, increased $11 \beta$ HSD1 activity in adipose tissue is associated with elevated fasting plasma insulin level [4]. Similar to obese zucker rat, WNIN/Ob obese rats have increased peripheral insulin resistance as indicated by elevated fasting insulin, HOMA-IR and increased glucose AUC. Despite of decreased peripheral insulin sensitivity, WNIN/Ob obese rats are not glucose intolerant, as glucose level reaches to normal at the end of second hour after oral glucose challenge (data not shown). As the obese rats have elevated $11 \beta$-HSD1 activity in adipose tissue, increased active 
glucocorticoids in adipose tissue might be responsible for the observed insulin resistance in this model.

Adipose tissue secrets various signaling molecules including cytokines like TNF- $\alpha$ and IL-6 [21]. Previous studies reported elevated levels of plasma TNF- $\alpha$ and IL-6 in obese rodent models and in humans, which are implicated in the development of obesity induced insulin resistance and diabetes [22,23]. Transgenic mice overexpressing $11 \beta-$ HSD1 in adipose tissue has elevated TNF- $\alpha$ mRNA and plasma TNF- $\alpha$, where as $11 \beta-$ HSD1 knock-out mice have decreased TNF- $\alpha$ mRNA in adipose tissue [24]. Recently, knock-down of $11 \beta$ HSD1 in pre-adipocytes has resulted in the decreased expression of IL-6 [25]. Although WNIN/Ob obese rats have elevated $11 \beta$-HSD1 activity in adipose tissue, plasma levels of TNF- $\alpha$ and IL- 6 levels are not elevated. This contrasting observation could be due to activation of other signaling mechanisms that can downregulate expression of TNF- $\alpha$ and IL- 6 in adipose and other tissues. Secretion of MCP-1 by adipose tissue is the key step in the recruitment of macrophages. In obesity, elevated plasma and adipose MCP-1 levels are reported along with increased tissue macrophages [26]. 11 $\beta$ HSD1 inhibition has been shown to decrease MCP-1 expression in adipose tissue [27]. Although plasma MCP-1 levels showed a trend towards increase, the observation is not statistically significant due to large variation.

Liver exhibits significant $11 \beta$-HSD1 activity and is also the main organ for the conversion of inactive glucocorticoids to active glucocorticoids [28]. Functional studies have shown that transgenic overexpression of $11 \beta$-HSD1 in liver results in insulin resistance, hepatic steatosis without causing obesity [29]. On the contrary, $11 \beta$ HSD1 knock-out mice are resistant to high fat dietinduced metabolic syndrome [20]. Previous studies involving rodent models of obesity and in obese humans have reported lower $11 \beta$-HSD1 activity in liver, which is considered to be a compensatory mechanism to improve obesity associated insulin resistance [4-6]. In the present study, WNIN/Ob obese rats displayed lower hepatic $11 \beta$-HSD1 activity, which is in line with the previous observations.

Recently, we have also studied the impact of nutrients like vitamin A and polyunsaturated fattyacids on $11 \beta$ HSD1 activity in WNIN/Ob obese rats. Chronic challenging with vitamin A enriched diet, decreased 11 $\beta$-HSD1 activity in liver and adipose tissue of obese rats, with concomitant reduction in adiposity (unpublished data). A decreased trend in $11 \beta$-HSD1 activity in adipose tissue of obese rats was also observed with chronic feeding of diet-rich in n-6 polyunsaturated fattyacids (unpublished data).
In conclusion, WNIN/Ob obese rats have elevated levels of circulatory glucocorticoids, lower hepatic $11 \beta$ HSD1 activity and higher omental and subcutaneous HSD1 activity. WNIN/Ob obese rats show several biochemical and physiological features similar to human obesity, particularly with regard to tissue glucocorticoid metabolism. Based on these observations, we propose that, WNIN/Ob obese rat not only serve as a good model to study the role of $11 \beta$-HSD1 in the development of obesity and metabolic syndrome, but also to study the effect of $11 \beta-$ HSD1 inhibitors and 11 $\beta$-HSD1 regulating nutrients in the amelioration of obesity and metabolic syndrome.

\section{Authors' contributions and information}

SSSVP involved in the animal handling, tissue dissection, plasma assays, and enzyme assay and prepared the first draft. AP and JSR involved in cytokine assays, PKC involved in the enzyme assay. GNV involved in the animal breeding and provided WNIN/Ob obese rats. VA drafted the manuscript and had overall supervision and gave final approval of the manuscript to be published. All authors have read and approved the final manuscript.

\section{Abbreviations}

11 $\beta$-HSD1: 11 $\beta$-hydroxysteroid dehydrogenase type 1.

\section{Acknowledgements}

We are grateful to Dr.B.Sesikiran, Director, of the institute for constant encouragement during the conduct of the study. Mr.S.S.S.V.Prasad thanks the Council for Scientific and Industrial Research (CSIR), India for the award of a research fellowship. Mr. S.M. Jeya Kumar was acknowledged for helping in HPLC work.

\section{Author details}

${ }^{1}$ Department of Biochemistry, National Institute of Nutrition, Jamai Osmania PO, Hyderabad-500 604, Andhra Pradesh, India. ${ }^{2}$ National center for Laboratory Animal Sciences, Indian Council of Medical Research, Jamai Osmania PO, Hyderabad-500 604, Andhra Pradesh, India.

\section{Competing interests}

The authors declare that they have no competing interests.

Received: 29 August 2010 Accepted: 17 November 2010 Published: 17 November 2010

\section{References}

1. Rosmond R, Dallman MF, Bjorntorp P: Stress-related Cortisol secretion in men: relationships with abdominal obesity and endocrine, metabolic, and hemodynamic abnormalities. J Clin Endocrinol Metab 1998, 77:1853-1859.

2. Tomilson JW, Walker EA, Bujalska IJ, Draper N, Lavery GG, Cooper MS, Hewison M, Stewart PM: 11 beta-hydroxysteroid dehydrogenase type 1: A tissue-specific regulator of glucocorticoid response. Endo reviews 2004, 25:831-866.

3. Draper N, Stewart PM: 11beta-hydroxysteroid dehydrogenase and the pre-receptor regulation of corticosteroid hormone action. J Endocrinol 2005, 186:251-271

4. Livingstone DEW, Jones GC, Smith K, Jamison PM, Andrew R, Kenyon CJ, Walker BR: Understanding the role of glucocorticoids in obesity: Tissue- 
specific alterations of corticosterone metabolism in obese zucker rats. Endocrinology 2000, 141:560-563.

5. Rask E, Olsson T, Soderberg S, Andrew R, Livingstone DE, Johnson O, Walker BR: Tissue-specific dysregualtion of cortisol metabolism in human obesity. J Clin Endocrinol Metab 2001, 86:1418-1421.

6. Paulmyer-Lacroix O, Boullu S, Oliver C, Alessi MC, Grino M: Expression of the mRNA coding for 11beta-hydroxysteroid dehydrogenase type 1 in adipose tissue from obese patients: an in situ hybridization study. $J$ Clin Endocrinol Metab 2002, 87:2701-2705.

7. Masuzaki H, Paterson J, Shinyama H, Morton NM, Mullins JJ, Seckl JR, Flier JS: A transgenic model of visceral obesity and the metabolic syndrome. Science 2001, 294:2166-2170.

8. Morton N, Paterson JM, Masuzaki H, Holmes MC, Stales B, Fievet C, Walker BR, Flier JS, Mullins JJ, Seckl JR: Novel adipose tissue-mediated resistance to diet-induced visceral obesity in 11beta-hydroxysteroid dehydrogenase type 1-deficient mice. Diabetes 2004, 53:931-938.

9. Giridharan NV, Harishankar N, Satyavani M: A new rat model for the study of obesity. Scand J Lab Anim Sci 1996, 23:131-137.

10. Matthews JN, Altman DG, Cambell MJ, Royston P: Analysis of serial measurements in medical research. BMJ 1990, 230-235.

11. Livingstone DEW, Grassick SL, Currie GL, Walker BR, Andrew R. Dysregualtion of glucocorticoid metabolism in murine obesity: comparable effects of leptin resistance and deficiency. J Endocrinol 2009, 201:211-218

12. Hauner H, Schmid P, Pfeiffer EF: Glucocorticoids and insulin promote the differentiation of human adipocyte precursor cells in to fat cells. $J$ Clin Endocrinol Metab 1987, 64:832-835.

13. Bujalska IJ, Kumar S, Hewison M, Stewart PM: Differentiation of adipose stromal cells: the roles of glucocorticoids and 11 beta-hydroxysteroid dehydrogenase. Endocrinology 1999, 140:3188-3196.

14. Morton NM, Densmore V, Wamil M, Ramage L, Nichol K, Bunger L, Seckl JR, Kenyon CJ: A polygenic model of the metabolic syndrome with reduced circulating and intra-adipose glucocorticoid action. Diabetes 2005, 54:3371-78.

15. Morton NM, Ramage L, Seckl JR: Down-regulation of adipose 11 betahydroxysteroid dehydrogenase type 1 by high-fat feeding in mice: A potential adaptive mechanism counteracting metabolic disease. Endocrinology 2004, 145:2707-2712.

16. Voice MW, Seckl JR, Edwards CRW, Chapman KE: 11 beta-hydroxysteroid dehydrogenase type 1 expression in 2S FAZA hepatoma cells is hormonally regulated: a model system for the study of hepatic glucocorticoid metabolism. Biochemical Journal 1996, 317:621-625.

17. Napolitano A, Voice MW, Edwards CR, Seckl JR, Chapman KE: $11 \beta$ hydroxysteroid dehydrogenase 1 in adipocytes: expression is differentiation-dependent and hormonally regulated. I Steroid Biochem Mol Biol 1998, 64:251-260.

18. Tomlinson JW, Moore J, Cooper MS, Bujalska I, Shahmanesh M, Burt C, Strain A, Hewison M, Stewart PM: Regulation of expression of 11hydroxysteroid dehydrogenase type 1 in adipose tissue: tissue-specific induction by cytokines. Endocrinology 2001, 142:1982-1989.

19. Qi D, Rodrigues B: Glucocorticoids produce whole body insulin resistance with changes in cardiac metabolism. Am J Physiol Endocrinol Metab 2007, 292:E654-E667.

20. Morton NM, Holmes MC, Fievet C, Staels B, Tailleux A, Mullins JJ, Seckl JR: Improved lipid and lipoprotein profile, hepatic insulin sensitivity, and glucose tolerance in 11 beta-hydroxysteroid dehydrogenase type 1 null mice. J Biol Chem 2001, 276:41293-41300.

21. Kershaw EE, Flier JS: Adipose tissue as an endocrine organ. J Clin Endocrinol Metab 2004, 89:1325-1335.

22. Hotamisligil GS, Arner P, Caro JF, Atkinson RL, Spiegelman BM: Increased adipose tissue expression of tumor necrosis factor- in human obesity and insulin resistance. J Clin Inves 1995, 95:2409-2415.

23. Wisse BE: The inflammatory syndrome: the role of adipose tissue cytokines in metabolic disorders linked to obesity. J Am Soc Nephrol 2004, 15:2792-2800.

24. Seckl JR, Morton NM, Chapman KE, Walker BR: Glucocorticoids and 11 betahydroxysteroid dehydrogenase in Adipose tissue. Recent Progress in Hormone Research 2004, 59:359-393.

25. Ishii-Yonemoto T, Masuzaki H, Yasue S, Okada S, Kozuka C, Tanaka T, Noguchi M, Tomita T, Fujikura J, Yamamoto Y, Ebihara K, Hosoda K, Nakao K: Glucocorticoid reamplification within cells intensifies NF- B and
MAPK signaling and reinforces inflammation in activated preadipocytes. Am J Physiol Endocrinol Metab 2010, 298:E930-E940.

26. Kanda H, Tateya S, Tamori Y, Kotani K, Hiasa K, Kitazawa R, Kitazawa S, Miyachi H, Maeda S, Egashira K, Kasuga M: MCP-1 contributes to macrophage infiltration into adipose tissue, insulin resistance, and hepatic steatosis in obesity. J Clin Invest 2006, 116(6):1494-1505.

27. Hermanowski-Vosatka A, Balkovec JM, Cheng K, Chen HY, Hernandez M, Koo GC, Le Grand CB, Li Z, Metzger JM, Mundt SS, Noonan H, Nunes CN, Olson SH, Pikounis B, Ren N, Robertson N, Schaeffer JM, Shah K, Springer MS, Strack AM, Strowski M, Wu K, Wu T, Xiao J, Zhang BB, Wright SD, Thieringer R: 11ß-HSD1 inhibition ameliorates metabolic syndrome and prevents progression of atherosclerosis in mice. J Exp Med 2005, 202:517-527.

28. Ricketts ML, Verhaeg JM, Bujalska I, Howie AJ, Rainey WE, Stewart PM: Immunohistochemical localization of type 111 beta-hydroxysteroid dehydrogenase in human tissues. J Clin Endocrinol Metab 1998, 83:1325-1335.

29. Paterson JM, Morton NM, Fievet C, Kenyon CJ, Holmes MC, Stales B, SeckI JR, Mullins JJ: Metabolic syndrome without obesity: hepatic overexpression of 11 beta-hydroxysteroid dehydrogenase type 1 in transgenic mice. Proc Natl Acad Sci USA 2004, 101:7088-7093.

doi:10.1186/1476-511X-9-132

Cite this article as: Prasad et al: A novel genetically-obese rat model with elevated 11 beta-hydroxysteroid dehydrogenase type 1 activity in subcutaneous adipose tissue. Lipids in Health and Disease 2010 9:132.

\section{Submit your next manuscript to BioMed Central and take full advantage of:}

- Convenient online submission

- Thorough peer review

- No space constraints or color figure charges

- Immediate publication on acceptance

- Inclusion in PubMed, CAS, Scopus and Google Scholar

- Research which is freely available for redistribution

Submit your manuscript at www.biomedcentral.com/submit
C Biomed Central 